\title{
Effect of dietary restraint during and following pegylated recombinant leptin (PEG-OB) treatment of overweight men
}

Citation for published version (APA):

Lejeune, M. P. G. M., Hukshorn, C. J., Saris, W. H. M., \& Westerterp-Plantenga, M. S. (2003). Effect of dietary restraint during and following pegylated recombinant leptin (PEG-OB) treatment of overweight men. International Journal of Obesity, 27(12), 1494-1499. https://doi.org/10.1038/sj.ijo.0802431

Document status and date:

Published: 01/01/2003

DOI:

10.1038/sj.ijo.0802431

Document Version:

Publisher's PDF, also known as Version of record

\section{Please check the document version of this publication:}

- A submitted manuscript is the version of the article upon submission and before peer-review. There can be important differences between the submitted version and the official published version of record. People interested in the research are advised to contact the author for the final version of the publication, or visit the DOI to the publisher's website.

- The final author version and the galley proof are versions of the publication after peer review.

- The final published version features the final layout of the paper including the volume, issue and page numbers.

Link to publication

\footnotetext{
General rights rights.

- You may freely distribute the URL identifying the publication in the public portal. please follow below link for the End User Agreement:

www.umlib.nl/taverne-license

Take down policy

If you believe that this document breaches copyright please contact us at:

repository@maastrichtuniversity.nl

providing details and we will investigate your claim.
}

Copyright and moral rights for the publications made accessible in the public portal are retained by the authors and/or other copyright owners and it is a condition of accessing publications that users recognise and abide by the legal requirements associated with these

- Users may download and print one copy of any publication from the public portal for the purpose of private study or research.

- You may not further distribute the material or use it for any profit-making activity or commercial gain

If the publication is distributed under the terms of Article 25fa of the Dutch Copyright Act, indicated by the "Taverne" license above, 


\title{
PAPER
}

\section{Effect of dietary restraint during and following pegylated recombinant leptin (PEG-OB) treatment of overweight men}

\author{
MPGM Lejeune $^{1 *}$, CJ Hukshorn ${ }^{1}$, WHM Saris ${ }^{1}$ and MS Westerterp-Plantenga ${ }^{1}$ \\ ${ }^{1}$ Department of Human Biology, Maastricht University, Maastricht, The Netherlands
}

OBJECTIVE: To examine the effect of dietary restraint during and following pegylated recombinant leptin (PEG-OB protein) treatment in overweight men.

DESIGN: A randomized double-blind placebo-controlled trial in 24 overweight men (BMI: $28.8 \pm 0.3 \mathrm{~kg} / \mathrm{m}^{2}$; age: $34.8 \pm 0.9 \mathrm{y}$ ). PEG-OB protein $(80 \mathrm{mg}$ ) or placebo was administered subcutaneously weekly for 6 weeks, combined with a $2.1 \mathrm{MJ} /$ day energy restriction program. Dietary restraint was determined by the Three-Factor Eating Questionnaire before and after treatment, and after 8 weeks follow-up.

RESULTS: During treatment dietary restraint increased, and general hunger, resting energy expenditure and respiratory quotient decreased similarly in the PEG-OB and the placebo group. With PEC-OB treatment, additional weight loss $(P<0.03)$ was observed. During 8 weeks follow-up, body weight increase was larger in the PEG-OB group compared to placebo $(P<0.05)$, and body weight regain was faster. Body weight regain was inversely correlated with the increase in cognitive dietary restraint during treatment (PEG-OB group: $r^{2}=0.49, P<0.02$; placebo group: $r^{2}=0.60, P=0.01$ ).

CONCLUSION: Although treatment with PEG-OB protein led to a greater body weight loss relative to placebo, weight maintenance thereafter was mainly supported by dietary restraint, which was more effective in the placebo-treated group, resulting in a slower regain of body weight.

International Journal of Obesity (2003) 27, 1494-1499. doi:10.1038/sj.ijo.0802431

Keywords: three-factor eating questionnaire; PEG-OB protein; dietary restraint; leptin; weight loss

\section{Introduction}

In many Western European countries and in the USA, the prevalence of overweight and obesity has increased over the last few decades. ${ }^{1}$ Obesity is associated with a relatively high rate of morbidity and early mortality if it remains untreated. ${ }^{2-5}$ Commonly used weight control methods such as diet and exercise ${ }^{6}$ as well as pharmacological approaches ${ }^{7}$ often are successful in the short term, but in the long term an increased risk of body weight regain resulting in weight cycling has been reported. ${ }^{6,8,9}$ Thus,

*Correspondence: MPGM Lejeune, Department of Human Biology, Maastricht University, PO Box 616, 6200 MD Maastricht, The Netherlands.

E-mail: M.Lejeune@HB.UNIMAAS.NL

Received 16 October 2002; revised 7 April 2003;

accepted 27 May 2003 other treatments that may be effective in the long term are necessary.

In this respect, the identification of leptin (or OB-protein, a circulating protein hormone) following the positional cloning of the $o b$ gene $^{10}$ as a possible energy balance regulator is of interest. Expression of the $o b$ gene is present in, for example, adipose tissue and the placenta. ${ }^{11}$ Leptin concentration in the serum changes in response to factors known to affect body weight. ${ }^{11,12}$ It has been demonstrated that blood levels of leptin correlated with percentages of body fat, and were elevated in obese individuals. ${ }^{13}$ In spite of elevated concentrations of leptin, which should reduce food intake and body fat, obese subjects appear to be insensitive or resistant to leptin, and continue to maintain increased body fat. With weight reduction, obese subjects were reported to lower leptin concentrations, which increased again with weight regain. ${ }^{14}$ 
In previous trials, significant dose-related reductions in body fat and body weight were observed following daily subcutaneous treatment with from 0.01 to $0.30 \mathrm{mg} / \mathrm{kg}$ recombinant human met-leptin for 24 weeks in obese subjects. ${ }^{15}$ The treatment of a young obese girl with daily met-leptin caused a reduction in appetite, food-seeking behavior, food intake and body weight. ${ }^{16}$ In a previous study with administration of $20 \mathrm{mg} /$ week pegylated recombinant human leptin, we found that appetite in the postabsorptive state was reduced, but no difference in body mass loss or body composition compared to placebo treatment was demonstrated. ${ }^{17}$ In that study, hunger (factor 3 , Three-Factor Eating Questionnaire (TFEQ); Stunkard and Messick ${ }^{18}$ ) was reduced in the PEG-OB group and cognitive restraint (factor 1, TFEQ) was increased in the placebo group during treatment.

In addition to physiological parameters, psychological parameters that play a role in the treatment of obesity have to be taken into account. Changes in attitude towards eating measured with the TFEQ following a weight reduction program have been observed in that these support weight maintenance. ${ }^{19-22}$ The TFEQ measures three factors relevant to human attitude towards eating; cognitive restraint, disinhibition and hunger. It is often seen that the cognitive restraint score increases during an energy restriction program, while the disinhibition and hunger scores decrease. ${ }^{19-22}$ The success of weight maintenance after a weight reduction program has been shown to be a function of increase in cognitive restraint during weight reduction. ${ }^{20,23}$ The relationship between dietary restraint and endogenous leptin levels has been studied in overweight women, but no significant correlation was found. ${ }^{24,25}$ To our knowledge, this relationship has not yet been investigated in overweight men. The question remains whether pharmacological treatment, that is, PEG-OB protein treatment, replaces or supports an increase of dietary restraint during treatment. Moreover, the effect of PEG-OB protein treatment on subsequent weight maintenance remains to be described. The aim of this study was to assess the role of dietary restraint during treatment with PEG-OB protein, and during the first period of weight maintenance thereafter.

\section{Subjects and methods \\ Subjects}

A total of 24 healthy overweight male volunteers (BMI; $25-32 \mathrm{~kg} / \mathrm{m}^{2}$, age: $18-40 \mathrm{y}$ ) were recruited by an advertisement in a local newspaper. Subjects who were willing to participate in the study were screened medically. A written informed consent was obtained from all the participants. Screening included a detailed medical history, a physical examination, biochemical tests of renal, hepatic, metabolic and hematological function, 12-lead resting electrocardiogram and vital signs. Subjects were nonsmokers, had a stable body weight ( $<3 \mathrm{~kg}$ change) over the last 3 months and did not receive prescription medication. Subjects with a history of atopy or hypersensitivity to pegylated proteins were excluded from the study. The study was approved by the Medical Ethics Committee of the University of Maastricht.

\section{Study design}

This single-center trial had a prospective, randomized, double-blind and placebo-controlled group design. After screening, 24 subjects were enrolled. The study was divided into three phases: (a) baseline characterization; (b) PEG-OB or placebo treatment and a very low-energy diet (VLED) for 6 weeks and (c) follow-up for 8 weeks. Subjects were matched in a pairwise manner with respect to age, BMI, fasting serum leptin and insulin concentration. Subsequently, the subjects of the matched pair were randomly assigned either to the treatment or to the placebo group.

Phase a: baseline characterization. In the 2 weeks before the start of the diet and treatment period, baseline measurements were performed. These measurements consisted of body weight, body composition, serum levels of leptin, resting energy expenditure (REE), respiratory quotient (RQ) and attitude towards eating characterized using a Dutch translation of the TFEQ. ${ }^{18,26}$ All subjects were asked to maintain their body weight during the baseline period and their normal physical activity level throughout the study period.

Phase b: 6 weeks treatment. At the start of the treatment period (day 1), all subjects were prescribed a VLED for 6 weeks to induce a state of semistarvation. At the same time, treatment consisting of injections of either $80 \mathrm{mg}$ PEG-OB $(8 \mathrm{ml}, 10 \mathrm{mg} / \mathrm{ml}$ ) (provided by Hoffmann-La Roche Inc., Nutley, NJ, USA) or matching placebo $(8 \mathrm{ml})$ was given subcutaneously in the para-umbilical region, once a week, during the VLED period. At the end of the 6-week treatment period, measurements of body weight, body composition, REE, RQ and attitude towards eating were performed again.

Phase c: 8 weeks follow-up. After week 6, the VLED and PEG-OB or placebo injections were stopped. After 4 and 8 weeks, body weight and attitude towards eating measurements were repeated.

Safety was monitored throughout the study by documentation of adverse events, recording of vital signs, regular urine analysis and routine measurements of serum chemistry and blood cell counts. Standard clinical chemistry and blood cell counts were conducted at the certified central laboratory of the University Hospital Maastricht, The Netherlands. 
1496

\begin{tabular}{l|c|c|c|}
\hline Phase a & Phase b & Phase c \\
Baseline & VLED + injections & Follow-up \\
\hline TFEQ & TFEQ & TFEQ \\
BW & BW & BW \\
REE/RQ & REE/RQ \\
LEP $\quad$ TFEQ \\
TFEQ: $\quad$ Three-Factor Eating Questionnaire \\
BW: $\quad$ Body weight \\
BC: $\quad$ Body composition \\
REE/RQ: Resting energy expenditure and RQ \\
LEP: $\quad$ Serum leptin concentration
\end{tabular}

\section{PEG-OB protein}

Polyethylene glycols (PEG), expressed and purified from Escherichia coli, are amphophilic polymers of ethylene glycol with varying average molecular weights that can be activated and covalently attached to proteins. Modification of proteins with PEG has resulted in increased serum half-life and reduced immunogenicity to a number of proteins. ${ }^{27,28}$ The average molecular weight of branched PEG utilized is $42.000 \mathrm{Da}$ in a $1: 1$ ratio. ${ }^{29,30}$ To name the administered substance in its original way, and to discriminate between the administered substance and endogenous leptin, we use 'PEG-OB protein' for the human recombinant pegylated administered and 'leptin' for the endogenous substance.

\section{Diet}

All subjects participated in the energy restriction program. During the first 6 weeks, subjects received a VLED (Modifast, Novartis Nutrition, Breda, The Netherlands). This diet provided $2.1 \mathrm{MJ} /$ day (three servings/day) and was a proteinenriched formula diet, containing $50 \mathrm{~g}$ carbohydrates, $52 \mathrm{~g}$ protein, $7 \mathrm{~g}$ fat and a micronutrient content that meets the Dutch recommended daily allowance. From week 7 until week 10 , subjects increased their energy intake gradually. They received less formula diet and were instructed to complete this with a free choice of food items. In weeks 7 and 8 , subjects still received $1.4 \mathrm{MJ} /$ day (two servings/day) of the formula diet. In weeks 9 and 10 , they received $0.7 \mathrm{MJ} /$ day (one serving/day).

\section{Measurements}

Body mass and body composition. Body weight was measured on a calibrated digital scale (Sauter D-7470, Ebingen, Germany) accurate to $0.1 \mathrm{~kg}$ and height was measured to the nearest $0.01 \mathrm{~m}$ using a wall mounted stadiometer (Seca, model 220, Hamburg, Germany). BMI was calculated from weight and height $\left(\mathrm{kg} / \mathrm{m}^{2}\right)$. Body composition was determined after an overnight fast by using the combination of hydrodensitometry and deuterium dilution according to the Maastricht protocol. ${ }^{31}$ Body composition was calculated according to the equations of Siri. ${ }^{32}$

Serum leptin levels. Fasting blood samples for the measurement of serum concentrations of leptin were collected. Serum leptin concentrations were measured according to the method described previously. ${ }^{33}$

Attitude towards eating. Attitude towards eating was characterized using a Dutch translation of the TFEQ. ${ }^{18,26}$ The first factor of the TFEQ (F1) measures cognitive restrained eating: control of food intake by thought and will power. The second factor (F2) represents disinhibition: an incidental inability to resist eating cues, or inhibition of dietary restraint (F1), and emotional eating. The third factor (F3) examines the subjective feeling of general hunger.

REE and substrate oxidation. REE and substrate oxidation were measured with the use of a ventilated hood after the subjects fasted overnight. After the subjects had been supine for $15 \mathrm{~min}$, their oxygen consumption and carbon dioxide production were measured for $45 \mathrm{~min}$ by means of a computerized open-circuit ventilated hood system, similar to the analysis system described by Schoffelen et al. ${ }^{34} \mathrm{REE}$ and $\mathrm{RQ}$ were calculated according to the formulas of Weir. ${ }^{35}$

\section{Statistical analysis}

Data are presented as means \pm standard error of the mean (s.e.m.). A factorial ANOVA was used to determine the possible difference between the PEG-OB and placebo group in all measured parameters. Possible differences of the variables over time between the groups were analyzed with a two-factor repeated-measures ANOVA. Post hoc analyses were performed with the Scheffe F-test. The possible relationships between the TFEQ scores, body weight loss and body weight regain were assessed by regression analysis. A $P$-value of $<0.05$ was regarded as statistically significant. Statistical procedures were performed by using Statview SE+ Graphics (Abacus Concepts, Berkeley, CA, USA, 1988).

\section{Results}

The baseline characteristics of the subjects randomized to each treatment group were similar. Two subjects of the placebo group dropped out voluntarily after 1 week because they were not able to maintain the VLED. Since this study was part of a greater study, part of the results have been published elsewhere. ${ }^{36}$

Body weight, BMI, percentage body fat, fat-free mass and fat mass decreased significantly in both the groups 
(Table 1). At the end of the treatment period, the mean weight loss was $14.6 \pm 0.8 \mathrm{~kg}$ in the PEG-OB group compared to $11.8 \pm 0.9 \mathrm{~kg}$ in the placebo group $(P=0.027)$. BMI decreased more in the PEG-OB group compared to the placebo group $(P=0.049)$. No significant differences between the two groups were found for the decrease in percentage body fat, fat-free mass and fat mass (Table 1 ). The REE and RQ significantly decreased in both the groups after 6 weeks treatment (Table 1). None of the changes in REE and $\mathrm{RQ}$ were significantly different between both the groups.

The cognitive restraint score (factor $1, T F E Q$ ) increased significantly in both the groups during the treatment period. The disinhibition score (factor 2, TFEQ) decreased significantly in the PEG-OB group, but did not reach significance in the placebo group. However, the decrease in disinhibition score during the treatment period in the placebo group was positively correlated with the body weight loss during treatment $\left(r^{2}=0.43, P=0.04\right)$. The hunger score (factor 3 , TFEQ) decreased in both the groups. In the PEG-OB group, the decrease in hunger score during the 6 weeks of treatment was positively related to body weight loss during treatment $\left(r^{2}=0.56, P<0.01\right)$. No significant differences in changes in TFEQ scores were found between the two groups (Table 1). With respect to the serum leptin levels (Table 1), no differences were found between the two groups $(P=0.54)$ and no relationship was found between dietary restraint scores at the start of the treatment and serum leptin levels $(P=0.91)$.

The PEG-OB group showed significant increases in body weight and BMI after 4 and 8 weeks follow-up, and also from 4 to 8 weeks follow-up (Table 2). In the placebo group, a significant increase in body weight and BMI was found only after 8 weeks follow-up (Table 2). Body weight increase was slower in the placebo group than in

Table 1 Subject characteristics of the placebo and PEG-OB groups before and after 6 weeks of injections and VLED

\begin{tabular}{|c|c|c|c|c|c|c|c|}
\hline & \multicolumn{2}{|c|}{ Placebo $(n=10)$} & \multirow[b]{2}{*}{$\mathrm{P}^{\mathrm{a}}$ for time } & \multicolumn{2}{|c|}{ PEC-OB $(\mathbf{n}=12)$} & \multirow[b]{2}{*}{$\mathrm{P}^{\mathrm{a}}$ for time } & \multirow[b]{2}{*}{$\mathrm{p}^{\mathrm{b}}$ for $G \times T$ interaction } \\
\hline & Before & After & & Before & After & & \\
\hline Age $(y)$ & $36 \pm 0.9$ & & & $35 \pm 1.2$ & & & \\
\hline Serum leptin (ng/ml) & $7.6 \pm 1.2$ & & & $7.1 \pm 0.7$ & & & \\
\hline Weight $(\mathrm{kg})$ & $96.6 \pm 3.7$ & $84.8 \pm 4.0$ & 0.0001 & $97.9 \pm 1.9$ & $83.3 \pm 1.6$ & 0.0001 & 0.027 \\
\hline BMI $\left(\mathrm{kg} / \mathrm{m}^{2}\right)$ & $29.0 \pm 0.6$ & $25.4 \pm 0.7$ & 0.0001 & $29.1 \pm 0.4$ & $24.8 \pm 0.4$ & 0.0001 & 0.049 \\
\hline Fat-free mass $(\mathrm{kg})$ & $67.3 \pm 2.3$ & $64.9 \pm 2.7$ & 0.002 & $69.3 \pm 1.4$ & $65.6 \pm 1.3$ & 0.0007 & NS \\
\hline Fat mass $(\mathrm{kg})$ & $29.3 \pm 1.9$ & $19.9 \pm 1.7$ & 0.0001 & $28.3 \pm 2.0$ & $17.2 \pm 2.0$ & 0.0001 & NS \\
\hline Factor 1 & $5 \pm 1.0$ & $12 \pm 1.2$ & 0.0004 & $5 \pm 1.2$ & $12 \pm 1.2$ & 0.0001 & NS \\
\hline Factor 2 & $5 \pm 0.4$ & $4 \pm 0.9$ & ns & $5 \pm 0.7$ & $4 \pm 0.7$ & 0.006 & NS \\
\hline Factor 3 & $6 \pm 1.2$ & $3 \pm 1.1$ & 0.02 & $6 \pm 0.9$ & $3 \pm 1.1$ & 0.004 & NS \\
\hline REE & $8.62 \pm 025$ & $7.27 \pm 0.30$ & 0.001 & $8.71 \pm 0.19$ & $7.67 \pm 0.25$ & 0.001 & NS \\
\hline RQ & $0.81 \pm 0.01$ & $0.77 \pm 0.01$ & 0.05 & $0.82 \pm 0.01$ & $0.77 \pm 0.01$ & 0.05 & NS \\
\hline
\end{tabular}

Data are presented as mean \pm s.e.m. Factor 1: cognitive restraint; Factor 2: disinhibition; Factor 3: hunger. No significant differences were present between the groups before the 6-week treatment period.

aNOVA repeated measures.

${ }^{b}$ Group $\times$ time interaction (ANOVA two factors repeated measurement with interaction),

Table 2 Subjects characteristics of the placebo and PEG-OB groups after treatment and after 4 and 8 weeks of follow-up

\begin{tabular}{|c|c|c|c|c|c|c|c|}
\hline & \multicolumn{3}{|c|}{ Placebo $(n=10)$} & \multicolumn{3}{|c|}{$P E G-O B(n=12)$} & \multirow[b]{2}{*}{$\begin{array}{l}\text { pa for } G \times T \\
\text { interaction }\end{array}$} \\
\hline & $\begin{array}{c}\text { After } \\
\text { treatment }\end{array}$ & $\begin{array}{l}4 \text { weeks } \\
\text { follow-up }\end{array}$ & $\begin{array}{c}8 \text { weeks } \\
\text { follow-up }\end{array}$ & $\begin{array}{c}\text { After } \\
\text { Treatment }\end{array}$ & $\begin{array}{c}4 \text { weeks } \\
\text { follow-up }\end{array}$ & $\begin{array}{l}8 \text { weeks } \\
\text { follow-up }\end{array}$ & \\
\hline Weight $(\mathrm{kg})$ & $84.8 \pm 4.0$ & $85.8 \pm 3.7$ & $86.6 \pm 3.8^{\star}$ & $83.3 \pm 1.6$ & $84.2 \pm 1.6^{*}$ & $86.9 \pm 1.7^{k^{*}}$ & 0.03 \\
\hline BMI $\left(\mathrm{kg} / \mathrm{m}^{2}\right)$ & $25.4 \pm 0.7$ & $25.8 \pm 0.6$ & $26.0 \pm 0.6^{*}$ & $24.8 \pm 0.4$ & $25.1 \pm 0.4^{*}$ & $25.9 \pm 0.5^{\star^{\dagger}}$ & 0.03 \\
\hline Weight regain (\%) & & $6.8 \pm 4.3$ & $14.5 \pm 4.0$ & & $6.9 \pm 2.2$ & $25.4 \pm 5.5^{\dagger}$ & NS \\
\hline Factor 1 & $12 \pm 1.2$ & $13 \pm 1.5$ & $11 \pm 1.8$ & $12 \pm 1.2$ & $12 \pm 0.9$ & $12 \pm 1.0$ & NS \\
\hline Factor 2 & $4 \pm 0.9$ & $4 \pm 0.5$ & $3 \pm 0.6$ & $4 \pm 0.7$ & $4 \pm 0.8$ & $4 \pm 0.7$ & NS \\
\hline Factor 3 & $3 \pm 1.1$ & $1 \pm 0.5$ & $2 \pm 0.4$ & $3 \pm 1.1$ & $2 \pm 1.0$ & $2 \pm 0.9$ & NS \\
\hline
\end{tabular}

Data are presented as mean \pm s.e.m. For differences compared to after treatment (ANOVA repeated measures): ${ }^{*}<<0.01$. For differences compared to 4 weeks follow-up (ANOVA repeated measures): ${ }^{\dagger} P<0.005$. Factor 1: cognitive restraint; Factor 2: disinhibition; Factor 3: hunger.

${ }^{a}$ Group $\times$ time interaction (ANOVA two factors repeated measurement with interaction) for 4 vs 8 weeks follow-up. No group $\times$ time interaction was found between after treatment $v 54$ and 8 weeks follow-up. 


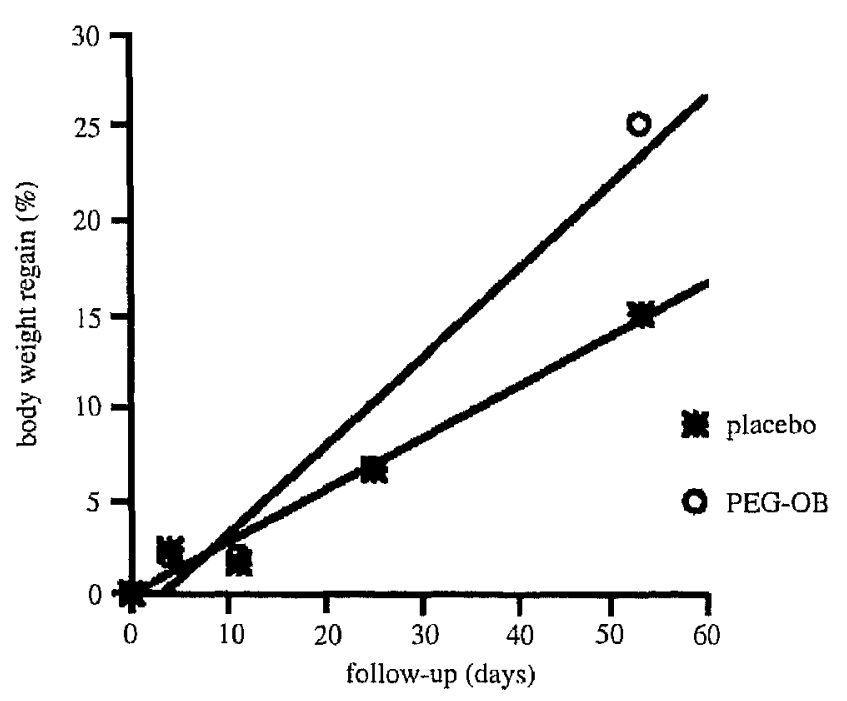

Figure 1 Body weight regain over time for the placebo $(n=10)$ and the PEG-OB $(n=12)$ group.

the PEG-OB group, as shown by the rates of body weight regain being expressed as \%regain $=0.47 \times$ follow-up days $-1.52\left(r^{2}=0.95, P=0.005\right)$ in the PEG-OB group and as $\%$ regain $=0.28 \times$ follow-up days $-0.003\left(r^{2}=0.98, P=0.002\right)$ in the placebo group (Figure 1).

Body weight regain during follow-up was, in the placebo group, inversely correlated with the change in cognitive restraint during follow-up $\left(r^{2}=0.60, P=0.01\right)$. The decrease in hunger score during follow-up in the placebo group correlated inversely with body weight regain during followup $\left(r^{2}=0.47, P=0.04\right)$. After 8 weeks of follow-up, body weight regain in the PEG-OB group was inversely correlated with the increase in cognitive restraint during the treatment period $\left(r^{2}=0.49, P<0.02\right)$. Body weight regain during follow-up was not related to initial body weight or body weight loss during the VLED (PEG-OB group: $P=0.40$; placebo group: $P=0.74$ ).

\section{Discussion}

The present study demonstrates that weight loss in both the groups (PEG-OB protein treated and placebo) was mainly supported by an increase in dietary restraint and a reduction in general hunger. However, additional weight loss in the PEG-OB group was due to the treatment of weekly subcutaneous injection of $80 \mathrm{mg}$ PEG-OB protein. ${ }^{36}$

Thus, results with respect to weight loss from comparable animal model studies ${ }^{37,38}$ and initial intervention studies in humans ${ }^{15,16}$ were reproduced in this study. ${ }^{36}$

The additional weight loss in the PEG-OB group during treatment was probably not a metabolic effect, because the reduction in the resting metabolic rate was similar for both the groups. This is in line with results that we reported previously, where metabolic effects were measured by means of a respiration chamber and also no differences between groups were found. ${ }^{17}$ Therefore, the additional weight loss can only be explained by a stronger reduction in food intake in the $\mathrm{PEG}-\mathrm{OB}$ group compared to the placebo group. During the 6-week treatment, the subjects in both the groups were in a negative energy balance and appeared to be in compliance with the energy deficit creating dietary instructions. Compliance with the dietary instructions independent of treatment was indicated by the increases in dietary restraint scores during the energy restriction program. The relationship between the decrease in general hunger scores and body weight loss during treatment in the PEG-OB group under negative energy balance conditions is in line with the reduced food intake in rats after PEG-OB protein treatment, ${ }^{37,38}$ and with the observations on reduction of appetite as reported by Farooqi et al. ${ }^{16}$

With respect to serum leptin levels, in this study with overweight men no relationship was found between dietary restraint and endogenous leptin levels. This is in line with results found in overweight women. ${ }^{24,25}$ The rate of body weight regain (expressed as percentage of the weight loss) after 8 weeks follow-up was larger in the PEG-OB than in the placebo group. Since there was no relationship between body weight regain and weight loss, this was not due to the larger body weight loss. An explanation could be that the placebo group experienced a greater support from changes in dietary restraint and in general hunger for weight maintenance than the PEG-OB group did. After 4 weeks follow-up, no significant differences in the percentage body weight regain between both the groups were seen yet, which can be explained by the long-lasting effect of the PEG-OB injections.

\section{Conclusion}

Although treatment with PEG-OB protein led to a greater body weight loss relative to placebo, weight maintenance was not supported by this treatment. On the contrary, dietary restraint was more effective in the first period of weight maintenance in the placebo treated group, resulting in a slower regain of body weight. It might be that pharmacological (PEG-OB protein) treatment limits the change in lifestyle necessary for weight maintenance after weight loss. For weight maintenance after PEG-OB treatment, this treatment might have to be continued, perhaps with a lower dosage.

\section{References}

1 Seidell JC. Dietary fat and obesity: an epidemiologic perspective. Am I Clin Nutr 1998; 67: 546S-550S.

2 National Institutes of Health Consensus Developments Panel on the Health Implications of Obesity. Health implications of obesity. Ann Intern Med 1985; 103: 1073-1077.

3 Lew E. Mortality and weight: insured lives and the American Cancer Society. Ann Intern Med 1985; 103: 1024-1029. 
4 Hubert $H$, Feinleid $M$, McNamara $P$, Casrelli WP. Obesity as an independent risk factor for cardiovascular disease: a 26-year follow-up of participants in the Framingham Heart Study. Circulation 1983; 67: 986-977.

5 Donahue R, Abbott RD, Bloom E, Reed DH, Yano K. Central obesity and coronary heart disease in men. Lancet 1987; 1 821-824.

6 Pasman WJ, Rössner S, Westerterp-Plantenga MS, Saris WHM. Body weight changes after treatment of obesity or pregnancy. In: Westerterp-Plantenga MS, Steffens A, Tremblay A (eds). Regulation of food intake. EDRA: Milan; 1999.

7 Hanotin C, Thomas F, Jones SP, Leutenegger E, Drouin P. A comparison of sibutramine and dexfenfluramine in the treatment of obesity. Obes Res 1998; 6: 285-291.

8 Muls $E$, Kempen $K$, Vansant $G$, Saris WHM. Is weight cycling detrimental to health? A review of the literature in humans. Int Obes Relat Metab Disord 1995; 19(Suppl 3): S46-S50.

9 Sjöstrom L, Rissanen A, Andersen $T$, Bolorin $M_{r}$ Golay A, Koppeschaar HP. Randomized placebo-controlled trial of orlistat for weight loss and prevention of weight regain in obese patients. Lancet 1998; 352: 167-172.

10 Zhang Y, Proenca R, Maffei M, Barone M, Leopold L, Friedman JM. Positional cloning of the mouse obese gene and its human homologue. Nature $1994 ; 372 ; 425-432$.

11 Campfield LA, Smith FJ, Guisez Y, Devos R, Burn P. The $O B$ protein (leptin) pathway: a link between adipose tissue mass and central neural networks. Horm Metob Res 1996; 28: 619-632.

12 Campfield LA, Smith FJ, Burn P. OB protein: a hormonal controller of central neural network mediating behavioral, metabolic and neuro endocrine responses. Endocrinol Metab 1997; 4: 81-102.

13 Considine RV, Sinha MK, Heiman ML, Kriauciunas A, Stephens TW, Nyce MR, Ohanisesian JP, Marco CC, McKee LY, Bauer TL. Serum immunoreactive-leptin concentrations in normal-weight and obese humans. $N$ Eng J Med 1996; 334: 292-295

14 Pasman WJ, Westerterp-Plantenga MS, Saris WHM. The effect of exercise training on leptin levels in obese males. Am J Physiol 1998; 274: E280-E286.

15 Heymsfield SB, Greenberg AS, Fujioka K, Dixon RM, Kushner R, Hunt $T$, Lubina JA, Patane J, Self B, Hunt P, McCahish $H$. Recombinant leptin for weight loss in obese and lean adults. A randomized, controlled dose-escalation trial. JAMA 1999; 282: $1568-1575$.

16 Farooqi LS, Jebb S, Langmack G. Effects of recombinant leptin therapy in a child with congenital leptin deficiency. $N$ Eng $/ \mathrm{Med}$ 1999; 341: 879-884

17 Westerterp-Plantenga MS, Saris WHM, Hukshorn CJ, Campfield LA. Effects of weekly administration of pegylated recombinant human $O B$-protein on appetite profile and energy metabolism in obese men. Am I Clin Nutr 2001; 74: 426-434.

18 Stunkard AJ, Messick S. The Three Factor Eating Questionnaire to measure dietary restraint, disinhibition and hunger. Psychol Res $1985 ; 29: 71-83$

19 Pasman WJ, Saris WHM, Westerterp-Plantenga MS. Predictors of weight maintenance. Obes Res 1999; 7: 43-50.

20 Westerterp-Plantenga MS, Kempen KP, Saris WHM. Determinants of weight maintenance in women after diet-induced weight reduction. Int I Obes Relat Metab Disord 1998; 22: 1-6.
21 Pekkarinen T, Takala I, Mustajoki P. Two year maintenance of weight loss after a VLCD and behavioral therapy for obesity: correlation to the scores of questionnaires measuring eating behavior. Int J Obes Relat Metab Disord 1996; 20: 332-337.

22 Clark MM, Marcus BH, Pera V, Niaura RS. Changes in eating inventory scores following obesity treatment. Int I Eat Disord 1994; 15:401-405.

23 Lejeune MPGM, Van Aggel DCP, Van Baak MA, WesterterpPlantenga MS. Dietary restraint during weight maintenance with or without exercise training, in men. Eur J Clin Nutr (in press).

24 d'Amore A, Massignan C, Montera P, Moles A, De Lorenzo A, Scucchi S. Relationship between dietary restraint, binge eating, and leptin in obese women. Int J Obes Relat Metab Disord 2001; 25: 373-377.

25 Von Prittwitz S, Blum WF, Ziegler A, Scharmann S, Remschmidt $H$, Hebebrand J. Restrained eating, measured with the TFEQ is associated with low leptin levels in underweight females. Mol Psychiatry 1997; 2: 420-422.

26 Westerterp-Plantenga MS, Rolland V, Wilson SA, Westerterp KR, Satiety related to $24 \mathrm{~h}$ diet-induced thermogenesis during high protein/carbohydrate $v s$ high fat diets measured in a respiration chamber. Eur 7 Clin Nutr 1999; 53: 495-502.

27 Nucci ML, Shor R, Abuchoweski A. The therapeutic value of poly(ethylene glycol)-modified proteins. Adv Drug Delivery Rev 1991; 6: 133-151.

28 Fuertges $F$, Abuchoweski $A$. The clinical efficacy of poly(ethylene glycol)-modified proteins. / Controlled Rel 1990; 11: 139-148.

29 Campfield LA, Devos R, Guisez Y. Pegylated obese (OB) protein compositions. US Patent Number 6,025,324, 2/15/2000.

30 Bailon P, Campfield LA, Devos R. Pegylated obese (OB) protein compositions. US Patent Number 6,025,325, 2/15/2000.

31 Westerterp KR, Wouters L, Van Marken Lichtenbelt WD. The Maastricht protocol for the measurement of body composition and energy expenditure with labeled water. Obes Res 1995; 3(Suppl 1): 49-57.

32 Siri WE. The gross composition of the body. Adv Biol Med Physiol 1956; 4: 239-280

33 Hukshorn CJ, Saris WHM, Westerterp-Plantenga MS, Farid AR, Smith FJ, Campfield LA. Weekly subcutaneous pegylated recombinant native human leptin (PEG-OB) administration in obese men. I Clin Endocrinol Metab 2000; 85: 4003-4009.

34 Schoffelen PFM, Westerterp KR, Saris WHM, Ten Hoor F. A dual respiration chamber with automated calibration. I Appl Physiol 1997; 83: 2064-2072.

35 Weir JBDV. New methods for calculating metabolic rate with special references to protein metabolism. I Physiol 1949; 109: 1-9.

36 Hukshorn CJ, Westerterp-Plantenga MS, Saris WHM. Pegylated human recombinant leptin (PEG-OB) causes additional weight loss in severly energy-restricted, overweight men. Am / Clin Nutr 2003; 77: 771-776.

37 Kahler A, Geary N, Eckel LA, Campfield LA, Smith FJ, Langhans $W$. Chronic administration of $O B$ protein decreases food intake by selectively reducing meal size in male rat. Am J Physiol 1998; 275: R180-R185.

38 Eckel LA, Langhans W, Kahler A, Campfield LA, Smith FJ, Geary $N$. Chronic administration of $O B$ protein decreases food intake by selectively reducing meal size in female rat. Am / Physiol 1998; 275: R186-R193. 